\title{
Equilibrium moisture content (EMC) in Norway spruce during the first and second desorptions
}

Hoffmeyer, Preben; Engelund, Emil Tang; Thygesen, Lisbeth Garbrecht

\section{Published in:}

Holzforschung

DOI:

10.1515/HF.2011.112

Publication date:

2011

Document version

Publisher's PDF, also known as Version of record

Document license:

Other

Citation for published version (APA):

Hoffmeyer, P., Engelund, E. T., \& Thygesen, L. G. (2011). Equilibrium moisture content (EMC) in Norway spruce during the first and second desorptions. Holzforschung, 65(6), 875-882. https://doi.org/10.1515/HF.2011.112 


\section{Equilibrium moisture content (EMC) in Norway spruce during the first and second desorptions}

\author{
Preben Hoffmeyer ${ }^{1}$, Emil Tang Engelund ${ }^{1,2}$ and \\ Lisbeth G. Thygesen ${ }^{3, *}$ \\ ${ }^{1}$ Department of Civil Engineering, Technical University of \\ Denmark, Brovej, Building 118, DK-2800 Kgs. Lyngby, \\ Denmark \\ ${ }^{2}$ Wood Technology, Danish Technological Institute, \\ Gregersensvej, DK-2630 Taastrup, Denmark \\ ${ }^{3}$ Forest and Landscape, University of Copenhagen, \\ Rolighedsvej 23, DK-1958 Frederiksberg C, Denmark \\ * Corresponding author. \\ Forest and Landscape, University of Copenhagen, Rolighedsvej \\ 23, DK-1958 Frederiksberg C, Denmark \\ E-mail: 1gt@life.ku.dk
}

\begin{abstract}
It is a commonly accepted notion that the equilibrium moisture content (EMC) of wood at a given relative humidity $(\mathrm{RH})$ is highest during initial desorption of green wood due to an irreversible loss of hygroscopicity during the $1^{\text {st }}$ desorption. The basis for this notion is investigated by assessing how drying and saturation procedures influence the differences between the $1^{\text {st }}$ and the $2^{\text {nd }}$ desorption curves for Norway spruce (Picea abies (L.) Karst.) sapwood. The study establishes $1^{\text {st }}$ and $2^{\text {nd }}$ desorption isotherms for a variety of initial conditions and it covers the $\mathrm{RH}$ range from $60.1 \%$ to $99.9 \%$. The state of the water is not affected by oven-drying and rewetting as demonstrated by time domain low field NMR relaxometry. The results challenge the conclusions of earlier studies and indicate that in these studies the $2^{\text {nd }}$ desorption was initiated at much too low EMC and therefore fails to describe a boundary desorption isotherm. Instead, it becomes an intermediate desorption isotherm starting at the adsorption boundary curve and crossing over to eventually meet the desorption boundary curve. The results also show that vacuum drying at room temperature only gives a modest loss of hygroscopicity compared to the green state. Conversely, oven-drying at $103^{\circ} \mathrm{C}$ results in a more significant loss of hygroscopicity, except for $\mathrm{RH}$ above $96 \%$ where an increase in EMC surprisingly is seen.
\end{abstract}

Keywords: fiber saturation; first and second desorption isotherms; green wood; time domain low field NMR spectroscopy; wood-water relations.

\section{Introduction}

It is a commonly accepted notion that the equilibrium moisture content (EMC) of wood at a given relative humidity
(RH) is highest during initial desorption of green wood. More specifically, it is commonly accepted that after drying, any subsequent desorption from saturated condition produces lower values of EMC at RH above 60\%-70\% "indicating that there is an initial irreversible loss in hygroscopicity", (Skaar 1988). The scientific basis for the notion that the $2^{\text {nd }}$ desorption universally gives lower EMCs than the $1^{\text {st }}$ is often ascribed to Spalt (1958), though similar observations had earlier been reported for cotton (Urqhuart 1929; Urquhart and Eckersall 1930), beech wood (Barkas 1936), wood pulp (Seborg et al. 1938) and cellulose objects (Hermans 1949). Spalt (1958) subjected specimens of four different coniferous species to both a $1^{\text {st }}$ and a $2^{\text {nd }}$ desorption. By use of saturated salt solutions, six different RHs were obtained, the highest of which was $94 \%$. At this RH, a species dependent value of the moisture ratio (MR), defined as the ratio between the EMCs at the $1^{\text {st }}$ and $2^{\text {nd }}$ desorption, was recorded in the range of 1.1-1.2. At decreasing values of RH the MR also decreased, resulting in a merging of the two desorption isotherms somewhere between RH $62 \%$ and $78 \%$. Spalt initiated his specimens to the $2^{\text {nd }}$ desorption from a condition reached by heating a water reservoir to a temperature that caused condensation in the weighing tubes held at room temperature. In other words, the specimens were presumably exposed to air saturated with water vapor. The specimens in the weighing tubes were thought to be in a saturated condition after prolonged exposure to this climate. However, it may be questioned whether this procedure is a suitable reference condition for saturation of the wood fibers. If this is not the case, Spalt's $2^{\text {nd }}$ desorption curves are intermediate desorption curves initiated from a moisture state less than fiber saturation. Spalt's results show increasing MRs for increasing RH. Even higher MRs for RH values exceeding Spalt's maximum RH value of $94 \%$ would therefore be expected. However, results for the $92.6 \%-99.9 \%$ RH range produced as an unpublished spin-off from an earlier study (Thygesen et al. 2010) surprisingly suggested decreasing MR ratios, which prompted the present study.

The study of potential differences between the $1^{\text {st }}$ and $2^{\text {nd }}$ desorption is intimately linked to the concept of the fiber saturation point (FSP). A brief review of the FSP concept is therefore included here. The original definition (Tiemann 1906) relates FSP to the EMC where, the free water in the cell lumina has disappeared, the cell wall begins to dry and the strength begins to increase. However, as discussed by Hill (2008), these effects do not normally occur at the same EMC, so in practice the FSP is less well defined. Furthermore, both free water and unsaturated cell wall may exist simultaneously in different cells within the same specimen (Almeida and Hernández 2006a,b; Hernández and Pontin 2006; Hernández and Bizoň 1994; Araujo et al. 1992; Menon 
Table 1 Overview of sequence of events for the five different procedures employed to subject specimens to desorption measurements. The digit in the procedure label is a hint to $1^{\text {st }}$ or $2^{\text {nd }}$ desorption, respectively.

\begin{tabular}{lccccc}
\hline & \multicolumn{5}{c}{ Procedure labels } \\
\cline { 2 - 6 } & GREEN1 $^{\mathrm{a}}$ & VACUUM1 $^{2}$ & SATVAP2 $^{\mathrm{b}}$ & VACUUM2 & OVENDRY2 \\
\hline Drying & N/A & N/A & Vacuum & Vacuum & Oven-drying \\
& & & $\left(20^{\circ} \mathrm{C}\right)$ & $\left(20^{\circ} \mathrm{C}\right)$ & $\left(103^{\circ} \mathrm{C}\right)$ \\
Saturation & N/A & Vacuum & $\begin{array}{c}\text { Water } \\
\text { vapor }\end{array}$ & Vacuum & Vacuum \\
& & & & \\
\hline
\end{tabular}

${ }^{\text {a Simulating }} 1^{\text {st }}$ and ${ }^{\mathrm{b}} 2^{\text {nd }}$ desorption according to Spalt (1958).

et al. 1987). Stamm (1964) lists FSP determined from a variety of strength tests of Sitka spruce and arrives at an FSP in the $27 \%-30 \%$ range, or much the same as the FSP value obtained by extrapolation of the sorption isotherm from $98 \%$ $\mathrm{RH}$. Hence, for purposes of calculating the moisture dependency of physical and mechanical properties of wood, such an approach to find FSP is perfectly suitable. However, such an FSP is a nominal value. It represents neither a particular point on the sorption isotherm nor an upper value of EMC above which no more bound water is taken up. Stone and Scallan (1967) related FSP to "the amount of water contained within the water saturated cell wall'. They then argued that the FSP must be where there is a discontinuity in the range of void dimensions, and they defined this FSP in terms of water potential. The quoted authors exposed black spruce to humidity in a pressure plate apparatus and found such a discontinuity at about $99.75 \% \mathrm{RH}$, equivalent to a matrix water potential of about $\psi_{m}=-0.3 \mathrm{MPa}$ and a void radius of about $0.4 \mu \mathrm{m}$, i.e., large microvoids (Thygesen et al. 2010). The corresponding FSP was $40 \%$. The same authors found, by means of a solvent exchange technique (dextran 110), a FSP value of $42 \%$ for the same specimens. Griffin (1977) reanalyzed the results of Stone and Scallan (1967) and added his own results from pressure plate tests including two other coniferous species. The author then defined FSP as the water content of wood that is in equilibrium with $\psi_{m}=-0.1 \mathrm{MPa}(99.93 \% \mathrm{RH}$ and $1.5 \mu \mathrm{m}$ void radius) during desorption from the saturated state and arrived at $\mathrm{FSP}=43 \%$. Hill et al. (2005) calculated $\mathrm{FSP}=38 \%$ for Corsican pine sapwood by the solute exclusion method. Hernández and Bizoň (1994) investigated sugar maple by the pressure membrane technique combined with measurements of strength and shrinkage and found that loss of bound water begins in desorption around 42\% EMC. The present paper is based on the FSP definition as "the amount of water contained within the water saturated cell wall', (Stone and Scallan 1967). More specifically, FSP is chosen as the EMC of wood in equilibrium with $\psi_{m}=-0.1 \mathrm{MPa}(\mathrm{RH}=99.93 \%$, void radius $=1.5 \mu \mathrm{m})$ (Griffin 1977).

The hypothesis of the present study is that a more detailed understanding is needed in terms of the question how drying and saturation procedures affect the relation between the $1^{\text {st }}$ and $2^{\text {nd }}$ desorption isotherms and that the concept of Spalt (1958) and Skaar (1988) "indicating that there is an initial irreversible loss in hygroscopicity" needs to be revisited and reassessed. The study establishes $1^{\text {st }}$ and $2^{\text {nd }}$ desorption iso- therms for a variety of initial conditions and it covers the $60.1 \%-99.9 \% \mathrm{RH}$ range. The study comprises two test series. One series covers the RH range from $60.1 \%$ to $98.4 \%$ and thus includes the full RH range for which Spalt (1958) reported differences between the $1^{\text {st }}$ and the $2^{\text {nd }}$ desorption curves. The state of water in the various specimens is also studied by NMR relaxometry. Advanced versions of both high and low field NMR relaxometry have been introduced to the wood and paper sciences during the last decade (see for example Topgaard and Södermann 2001; Garvey et al. 2006; Johannessen et al. 2006; Kekkonen et al. 2009; Cox et al. 2010). In the present study, standard time domain low field NMR relaxometry (TD LF NMR) above and below the freezing point of free water was performed.

\section{Materials and methods}

Rectangular cuboids measuring $3 \times 23 \times 47 \mathrm{~mm}^{3}$ were cut from the sapwood of discs taken from a stem of Norway spruce (Picea abies (L.) Karst.). Processing of the stem took place within a few days after harvest, and care was taken throughout to prevent specimens from drying out. After processing, the specimens were stored in sealed plastic bags with an excess of demineralized water. The bags and their content were then subjected to neutron radiation $(1 \times 15 \mathrm{kGy})$ to prevent biological degradation by mold fungi during storage. As a further precaution, the sealed plastic bags were stored at $5^{\circ} \mathrm{C}$. Prior to further use, the specimens were removed from the bags and placed in demineralized water containing sodium azide $\left(\mathrm{NaN}_{3}, 200 \mathrm{mg} \mathrm{l}^{-1}\right)$ for more than $24 \mathrm{~h}$. Specimens prepared like this are here referred to as green specimens.

\section{Saturation and drying procedures}

Table 1 presents the procedure labels together with the five different procedures employed to subject specimens to desorption measurements. The digit 1 or 2 in the procedure label is a hint to $1^{\text {st }}$ or a $2^{\text {nd }}$ desorption, respectively. The GREEN1 procedure corresponds to that of Spalt (1958) to establish the $1^{\text {st }}$ desorption curve. The VACUUM1 procedure then reveals whether the green condition represents full saturation of the cell wall. The saturation over water vapor (SATVAP2) procedure attempts to mimic the water vapor saturation and vacuum drying procedure - as described by Spalt (1958) - applied for the $2^{\text {nd }}$ desorption. The efficiency of this procedure is assessed by the procedure VACUUM2, which employs liquid water instead of water vapor for the saturation prior to the $2^{\text {nd }}$ desorption. Finally, the OVENDRY2 procedure allows an assessment of any additional change of hygroscopicity arising from drying at elevated temperature. 
Demineralized water containing sodium azide $\left(\mathrm{NaN}_{3}, 200 \mathrm{mg} \mathrm{l}^{-1}\right)$ was used for the vacuum saturation. The specimens were first exposed to water for $1 \mathrm{~h}$ at $2.6-3.0 \mathrm{kPa}$ followed by $0.5 \mathrm{~h}$ at atmospheric pressure. They were then exposed to the water for more than $24 \mathrm{~h}$ at $2.6-3.0 \mathrm{kPa}$ followed by more than $6 \mathrm{~h}$ at atmospheric pressure. Vacuum drying was carried out in desiccators containing magnesium perchlorate as desiccant $\left(20^{\circ} \mathrm{C}\right.$ and $\left.0.1-1.0 \mathrm{kPa}\right)$. After two weeks, the desiccant was removed and constant pumping $\left(20^{\circ} \mathrm{C}\right.$ and $0.1 \mathrm{kPa}$ ) was carried out for an additional three days. At that point, the weight change of the specimens was about $0.03 \%$ per day. Exposure to saturated water vapor was started in desiccators at $20^{\circ} \mathrm{C}$ at a pressure of about $2.6-3.0 \mathrm{kPa}$. After 7 days, vacuum was replaced by atmospheric pressure to allow EMC to be reached under conditions comparable to those used by Spalt (1958). The total time for water vapor saturation was ten days. At that point, the weight change of the specimens was about $0.02 \%$ per day. Oven-drying was carried out at $103^{\circ} \mathrm{C}$ for a duration of about $24 \mathrm{~h}$. Specimens were taken directly from green condition to oven-drying.

\section{Conditioning $(60.1 \% \leq \mathrm{RH} \leq \mathbf{9 8 . 4} \%)$}

Six different levels of RH were achieved by saturated salt solutions in desiccators $\left(\mathrm{NaBr}, \mathrm{NaCl}, \mathrm{KCl}, \mathrm{BaCl}_{2}, \mathrm{KNO}_{3}\right.$ and $\left.\mathrm{K}_{2} \mathrm{SO}_{4}\right)$. The desiccators were placed in a $20^{\circ} \mathrm{C}$ water bath in an isolated chamber. The solutions were magnetically stirred to promote a uniform RH distribution within the desiccators. Five sets of cuboid specimens, corresponding to the five procedures, were placed in weighing glasses in each of the six desiccators. The 30 specimens were generally taken out and weighed once every $1-2$ weeks. The lids of the weighing glasses were mounted when opening a desiccator and taking out the glasses for weighing. Atmospheric pressure was reestablished immediately before opening any desiccator. This was done by filling the desiccator with air having a RH matching that of the desiccator. Air used for the filling of the dry desiccators had a dew point temperature of about $-100^{\circ} \mathrm{C}$ corresponding to a $\mathrm{RH}<0.01 \%$. The maximum time to equilibrium was about five months. The criterion for having reached EMC was a change of mass corresponding to $<0.01 \% \mathrm{MC}$ per day. Following the completion of the desorption measurements, all specimens were ovendried at $103^{\circ} \mathrm{C}$ for a minimum of $24 \mathrm{~h}$ and then weighed.

In a preceding paper (Thygesen et al. 2010), RH values corresponding to the saturated salt solutions were taken from literature. The present investigation demonstrated that stirring of the saturated salt solutions results in $\mathrm{RH}$ values in the desiccators slightly higher than would be expected from literature. The RH was therefore measured in situ by placing moisture data loggers in the desiccators. Instrument: Tinytag Explorer Version 4.6 (from Gemini Data Loggers Ltd., Chichester, UK). A Hygromer ${ }^{\circledR}$ HR 100A (from Rotronic AG, Bassersdorf, Switzerland) was used to calibrate the Tinytag data loggers. Traceability of measurements was assured by using the Rotronic calibration chamber in a combination with Rotronic's certified salt solution ampoules. The following calibrated RH values were found based on the in situ moisture measurements: $60.1 \%$ ( $\mathrm{NaBr}), 76.9 \%(\mathrm{NaCl}), 87.1 \%(\mathrm{KCl}), 92.6 \%\left(\mathrm{BaCl}_{2}\right), 95.1 \%\left(\mathrm{KNO}_{3}\right)$ and $98.4 \%\left(\mathrm{~K}_{2} \mathrm{SO}_{4}\right)$. These $\mathrm{RH}$ values, which are used in the following, exceed those reported in literature by about $1 \%$.

\section{Additional test series $(92.6 \% \leq \mathbf{R H} \leq \mathbf{9 9 . 9} \%)$}

A subset of the specimens were treated according to the processes GREEN1 and OVENDRY2. RH levels (21 totally) in the $92.6 \%-99.9 \%$ range were established at $20^{\circ} \mathrm{C}$ by three different methods: saturated salt solutions, climate chambers, and the pressure plate technique (PPT). For details about the methods see Thygesen et al. (2010).

\section{Time domain low field NMR relaxometry (TD LF NMR)}

A subset of the specimens from the additional test series were subjected to TD LF NMR (23 MHz ${ }^{1} \mathrm{H}$ NMR Maran instrument, from Resonance Instruments, now part of Oxford Instruments, Abingdon, UK) at $+20^{\circ} \mathrm{C}$ and $-20^{\circ} \mathrm{C}$. The free induction decay (FID) was recorded with a recycle delay of $2 \mathrm{~s}$ and 32 acquisitions. Eight thousand data points with a spacing of $0.5 \mathrm{~ms}$ were recorded. For further details see Thygesen et al. (2010).

\section{Results and discussion}

\section{Particular features of desorption isotherms at very high $\mathbf{R H}$ values}

Results from the additional test series $(92.6 \% \leq \mathrm{RH} \leq 99.9 \%)$ allow a discussion of characteristic features at the very high end of RH. Figure 1a shows the isotherms corresponding to the procedures GREEN1 and OVENDRY2. The markers refer to the three different methods employed for establishing the RH levels. As can be seen, the experiment was designed with overlaps between the three methods and the overlaps show that the EMCs recorded (obtained at the same RH by two or three methods for samples prepared using the same procedure) are not systematically different. In other words, the results show no discontinuities between methods and this feature lends the isotherms high credibility. Neither the green nor the dried and remoistened specimens show any signs of an upward bend as a result of capillary condensation, except perhaps above $99.5 \%$ RH. For the OVENDRY2 specimens, this has been discussed elsewhere (Thygesen et al. 2010; Engelund et al. 2010). The results do not indicate that the green specimens behave any differently, which supports the conclusion of (Thygesen et al. 2010; Engelund et al. 2010) that "capillary condensation does not play a significant role for water sorption below the FSP',

Figure 1 shows FSP values of the order $\mathrm{FSP} \approx 38 \%$ for the GREEN1 procedure and FSP $\approx 42 \%$ for the OVENDRY2 procedure. This order of magnitude is consistent with the results from the literature discussed in the preceding section on fiber saturation. It should be noted that the two isotherms cross around $96 \% \mathrm{RH}$ leaving the oven-dried specimens with a higher FSP than the green specimens.

\section{The significance of saturation procedures}

Green specimens are used throughout the tests as a reference representing never dried and fully saturated wood. A comparison of the desorption isotherm for the two types of green specimens GREEN1 and VACUUM1 (obtained by additional vacuum saturation with water) show very little difference (Figure 2a). It can be concluded that the GREEN1 specimens were indeed water saturated.

Figure $2 b$ shows MRs as a function of RH for each of the three $2^{\text {nd }}$ desorption procedures. The three procedures lead 

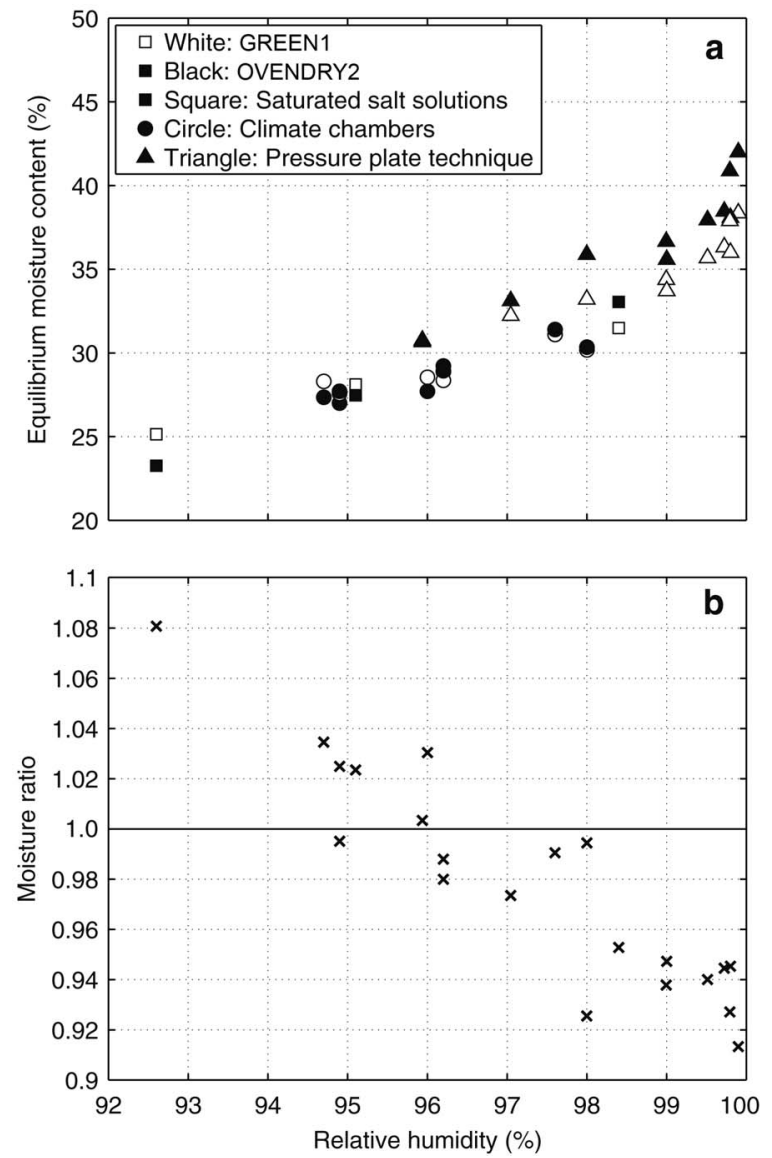

Figure 1 a) Comparison of desorption isotherms for Norway spruce sapwood for relative humidity (RH) in the range $92.6 \% \leq \mathrm{RH} \leq 99.9 \%$. First desorption isotherm (GREEN1) and second desorption isotherm (OVENDRY2). b) Corresponding moisture ratio (MR) as a function of $\mathrm{RH}$. MR is expressed as the ratio between the equilibrium moisture content (EMC) from procedure GREEN1 ( $1^{\text {st }}$ desorption) and the EMC for OVENDRY2 ( $2^{\text {nd }}$ desorption).

to very different results. This underlines the importance of the choice of procedure prior to the $2^{\text {nd }}$ desorption when attempting to assess a measure of irreversible change of hygroscopicity. The MR for the SATVAP2 desorption is representative of the procedure of Spalt (1958) and Urquhart and Eckersall (1930). A general trend is recognized towards increasing $\mathrm{MR}$ the higher the $\mathrm{RH}$. At $\mathrm{RH}=98.4 \%$, the $\mathrm{MR}$ is elevated to about 1.07 (Figure 2b). This behavior is in accordance with the findings of the quoted papers and we suggest that they are a result of an insufficient saturation prior to the $2^{\text {nd }}$ desorption. In order to test this hypothesis, SATVAP2 is compared with vacuum saturation with water (VACUUM2) (Figure 2c): at 98.4\% RH, the EMC of the SATVAP2-desorption was $30.1 \%$ while the EMC of the VACUUM2-desorption was $32.2 \%$. At higher RH values, this difference increases: the EMC of the SATVAP2 specimens after prolonged exposure to saturated water vapor was on average $31.2 \%$ or only marginally higher than the EMC obtained at $98.4 \% \mathrm{RH}$. Thus, exposure to an atmosphere of saturated water vapor does not result in saturation of the
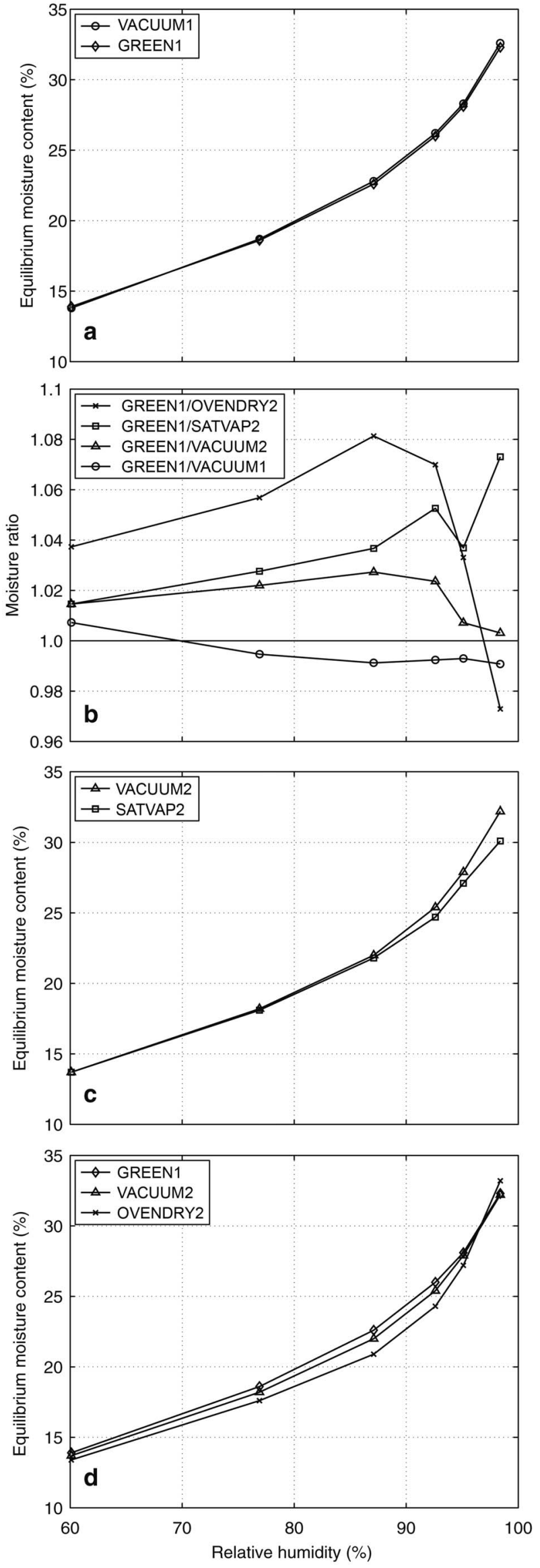


\begin{abstract}
Figure 2 a) Desorption isotherms for Norway spruce sapwood. Green specimens (GREEN1) and green specimens subjected to additional vacuum saturation with water (VACUUM1). b) Moisture ratio (MR) as a function of relative humidity (RH) for Norway spruce sapwood in the range $60.1 \% \leq \mathrm{RH} \leq 97.7 \%$. MR is expressed as the ratio between the equilibrium moisture content (EMC) from procedure GREEN1 ( $1^{\text {st }}$ desorption) and the EMC for VACUUM1 and for each of the three $2^{\text {nd }}$ desorption procedures. c) Desorption isotherms for Norway spruce sapwood. Second desorptions initiated from exposure to saturated water vapor (SATVAP2) or from vacuum saturation with water (VACUUM2). d) Desorption isotherms for Norway spruce sapwood. Illustration of irreversible change of hygroscopicity as a result of vacuum drying (GREEN1 vs. VACUUM2) or oven-drying at $103^{\circ} \mathrm{C}$ (GREEN1 vs. OVENDRY2).
\end{abstract}

wood cell wall, but rather produces an EMC representative of a $\mathrm{RH}$ around $98.5 \%$. In contrast, vacuum saturation of the specimens ensures initiation of the $2^{\text {nd }}$ desorption from a MC surpassing the FSP. The FSP for the green specimens was found to be $38 \%$. Thus, the SATVAP2-desorption is initiated at too low EMC. It therefore represents an intermediate isotherm starting at the adsorption boundary curve well below the FSP and then crossing over to eventually meet the desorption boundary curve at a RH value around 75\%-80\% (Figure 2c). The very fact that the SATVAP2 curve merges with the boundary curve (VACUUM2) shows the SATVAP2desorption curve to be an intermediate curve crossing the hysteresis area. Consequently, the results of Spalt (1958) do not give a quantitative assessment of irreversible loss of hygroscopicity. However, this does not exclude that such loss takes place as discussed below.

\section{The significance of drying procedures}

The impact of drying is illustrated in Figure $2 b$ and $2 d$ where the GREEN1-desorption is compared with the VACUUM2 and OVENDRY2 desorption isotherms. As would be expected, the Figures show that drying from the green state generally reduces the hygroscopicity, and also that oven-drying reduces hygroscopicity more than vacuum drying. Only at high values of $\mathrm{RH}$, the reverse turns out to be true.

Softening may explain the general decrease in hygroscopicity, and may also explain the difference seen between vacuum drying and oven-drying. Above the glass transition point $\left(\mathrm{T}_{\mathrm{g}}\right)$, amorphous polymers are in a rubbery state of mobility, whereas the mobility is highly restricted in the glassy state below this point. $\mathrm{T}_{\mathrm{g}}$ depends on both $\mathrm{MC}$ and temperature; the higher the $\mathrm{MC}$, the lower the $\mathrm{T}_{\mathrm{g}}$. In situ, lignin has a $\mathrm{T}_{\mathrm{g}}$ around $50-60^{\circ} \mathrm{C}$ at full saturation while it approaches $100^{\circ} \mathrm{C}$ as the MC drops below $10 \%$ (Kelley et al. 1987). Hemicelluloses have a lower $\mathrm{T}_{\mathrm{g}}$, i.e., below $0^{\circ} \mathrm{C}$ for full saturation and about room temperature for an $\mathrm{MC}$ of $10 \%$ (Kelley et al. 1987). During vacuum drying at room temperature in the VACUUM2 procedure, the hemicelluloses pass from the rubbery state present in the green wood to the glassy state, while the lignin remains in its glassy state. In the OVENDRY2 procedure, the specimens experience an initial short period of simultaneously high MC and high temperature. This means that both the lignin and the hemicelluloses have been in their rubbery states allowing greater mobility and thus facilitating a stress relaxation and a rearrangement of the wood polymers into an energetically more favorable state than what was possible at any time during the VACUUM2 procedure. The more mobile the lignin and the hemicelluloses, the more stable polymer-polymer hydrogen bonds will presumably form. Consequently, upon a subsequent resaturation and desorption, the hygroscopicity will be slightly lower due to a decrease in available sorption sites, thus yielding a MR above unity. This effect has been found for other materials, such as polymers (Watt 1980), collagen (Green 1948), and textile fibers (Jeffries 1960).

For both types of drying, the MR in Figure $2 \mathrm{~b}$ shows that a change occurs around $85 \% \mathrm{RH}$. Below this humidity, the MR decreases with decreasing $\mathrm{RH}$, whereas it decreases with increasing humidity above $85 \% \mathrm{RH}$. For the VACUUM2 specimens, the decrease in MR at high RH is less pronounced than that for the OVENDRY2 specimens. For VACUUM2, MR approaches unity for RH close to saturation. This implies that vacuum saturation restores the MC of vacuum dried wood to that of green wood, but that the sorption isotherm nevertheless lies below that of green wood throughout the RH range included in the study. The MR of OVENDRY2 specimens is below unity for very high RH. At $98.4 \%$ $\mathrm{RH}, \mathrm{MR} \approx 0.97$ corresponding to slightly higher MCs in the oven-dried specimens at high $\mathrm{RH}$ than in green wood following vacuum saturation, i.e., the desorption isotherm of the oven-dried specimens crosses that of green wood at approximately $96 \% \mathrm{RH}$. The same tendency was found in the additional tests at very high RH (Figure 1b), confirming that at these RH values the OVENDRY2-desorption isotherm lies above the GREEN1-desorption isotherm. To the best of the authors' knowledge this has not been documented earlier.

Capillary sorption could theoretically explain the higher MC in oven-dried wood at high RH compared to green wood. It is well known that heat treatment of wood can cause chemical degradation and removal of cell wall material (Stamm 1956). The microvoids left behind due to loss of material can cause an increased hygroscopicity at high RH due to capillary condensation, whereas the hygroscopicity at lower RH is decreased due to loss of sorption sites in the cell wall (Hoffmeyer et al. 2003). A similar change in hygroscopicity is evident for the OVENDRY2 specimens in Figure 2b. In this study, however, the temperature and duration of drying are considered insufficient to cause significant chemical degradation of the wood cell wall (Kollmann et al. 1969).

\section{Water in green and rewetted wood studied by TD LF NMR}

Drying stresses may cause microcracks which could lead to capillary condensation at high RH. A possible presence of such capillaries to allow condensation of water in the cell wall of the OVENDRY2 specimens may be assessed by testing a possible presence of freezable water (Petrov and Furó 2009). Therefore, TD LF NMR was carried out at +20 and at $-20^{\circ} \mathrm{C}$ for a subset of the OVENDRY2 and the GREEN1 specimens. Figure 3 shows the mean FIDs of the two sample 

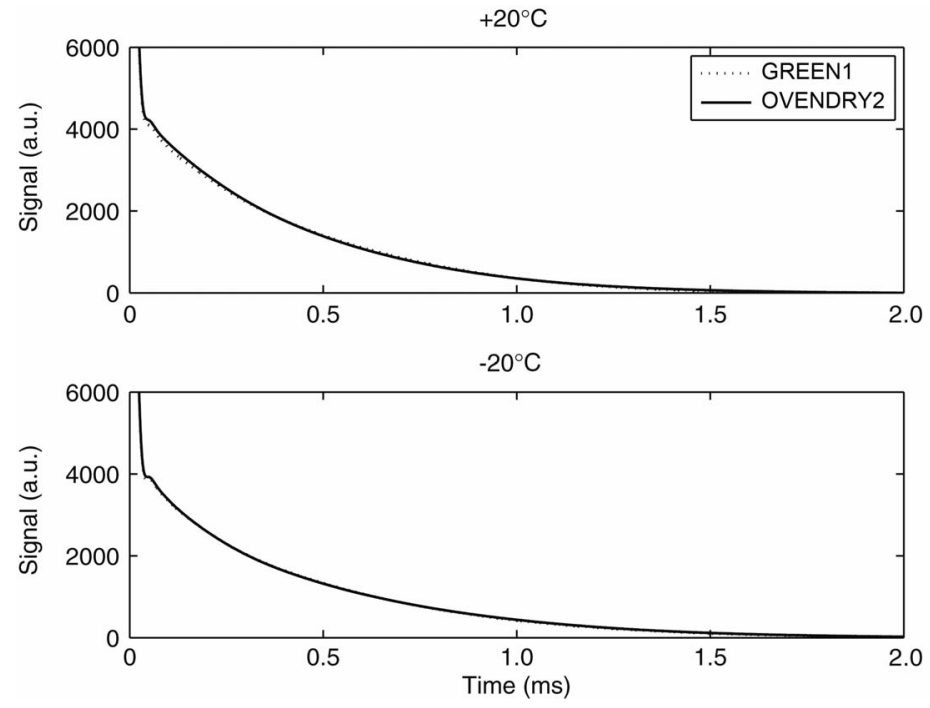

Figure 3 Mean free induction decay (FID) relaxation curves from LF TD NMR of 36 specimens of each of the two sample types GREEN1 and OVENDRY2 at $+20^{\circ} \mathrm{C}$ and at $-20^{\circ} \mathrm{C}$. Data for different moisture contents have been pooled.

types. All four mean curves appear to be almost identical. This indicates that neither sample type contained freezable water at temperatures as low as $-20^{\circ} \mathrm{C}$. This comparison based solely on mean FIDs may, however, be misleading as the specimens within the two samples contained different amounts of water, as seen in Figure 1a. In order to check for possible individual effects of freezing, a principal component analysis was carried out of the FIDs from both samples at both temperatures (Figure 4). This analysis shows that freezing did not affect the FIDs of the individual specimens systematically (Figure 4a and Figure 4b), albeit the amplitude of the effect does seem to be somewhat related to the MC (Figure 4c), regardless of treatment. In any case, the lack of systematic differences in the FIDs between the two samples and temperatures means that the state of the water in all specimens is similar, and that neither of the two samples contained any water that froze at $-20^{\circ} \mathrm{C}$. This temperature corresponds to freezing of water in microvoids with a radius down to $3 \mathrm{~nm}$ (Petrov and Furó 2009). Thus, the extra water present in OVENDRY2 specimens compared to GREEN1 specimens at high RH was not due to capillary condensation in microvoids, but must have been caused by increased amounts of bound water. That the EMC of oven-dried wood is higher than that of green wood close to saturation thus remains unexplained.

\section{Conclusions}

The study compares the desorption isotherms in the range from $60.1 \%$ to $99.9 \%$ RH for green Norway spruce sapwood ( $1^{\text {st }}$ desorption) with the sorption isotherms of similar specimens that had been dried and remoistened using a variety of procedures ( $2^{\text {nd }}$ desorptions). All desorption tests were carried out at $20^{\circ} \mathrm{C}$. The main conclusions are as follows:
- Exposure to an atmosphere of saturated water vapor does not result in saturation of the wood cell wall, but rather produces an EMC representative of a $\mathrm{RH}$ of around $98.5 \%$

- A $2^{\text {nd }}$ desorption curve initiated from a state of water vapor saturation represents an intermediate isotherm starting at the adsorption boundary curve well below the FSP and then crossing over to eventually meet the desorption boundary curve at a RH value around $75 \%-80 \%$. Vacuum saturation restores full saturation of the cell wall.

- The $2^{\text {nd }}$ desorption curve reveals only little change of hygroscopicity caused by drying at room temperature. At high $\mathrm{RH}$ no change is seen.

- Oven-drying at $103^{\circ} \mathrm{C}$ produces a loss of hygroscopicity for RH below $96 \%$. The loss is ascribed to the process history allowing a short period of both high temperature and MC. Both lignin and hemicelluloses then pass their glass transition and enter into a rubbery state. The resultant softening allows a rearrangement of the cell wall polymers into an energetically more favorable state resulting in fewer available sorption sites.

- Oven-drying at $103^{\circ} \mathrm{C}$ produces an increase of hygroscopicity for $\mathrm{RH}$ above $96 \%$. It is shown that the increase is not caused by capillary sorption in voids. The cause of this increase in hygroscopicity remains unexplained.

- The FSP defined as the EMC at a matrix potential $\psi_{m}=$ $-0.1 \mathrm{MPa}(\mathrm{RH}=99.93 \%$, void radius $=1.5 \mu \mathrm{m})$, is of the order $\mathrm{FSP} \approx 38 \%$ for the $1^{\text {st }}$ desorption of green specimens and $\mathrm{FSP} \approx 42 \%$ for the desorption of oven-dried specimens that are subsequently vacuum saturated.

- The shape of the desorption isotherm at high values of $\mathrm{RH}$ for green specimens confirms the findings reported in an earlier study (Thygesen et al. 2010; Engelund et al. 2010) regarding the modest role of capillary condensation in wood-water relations below the FSP. 

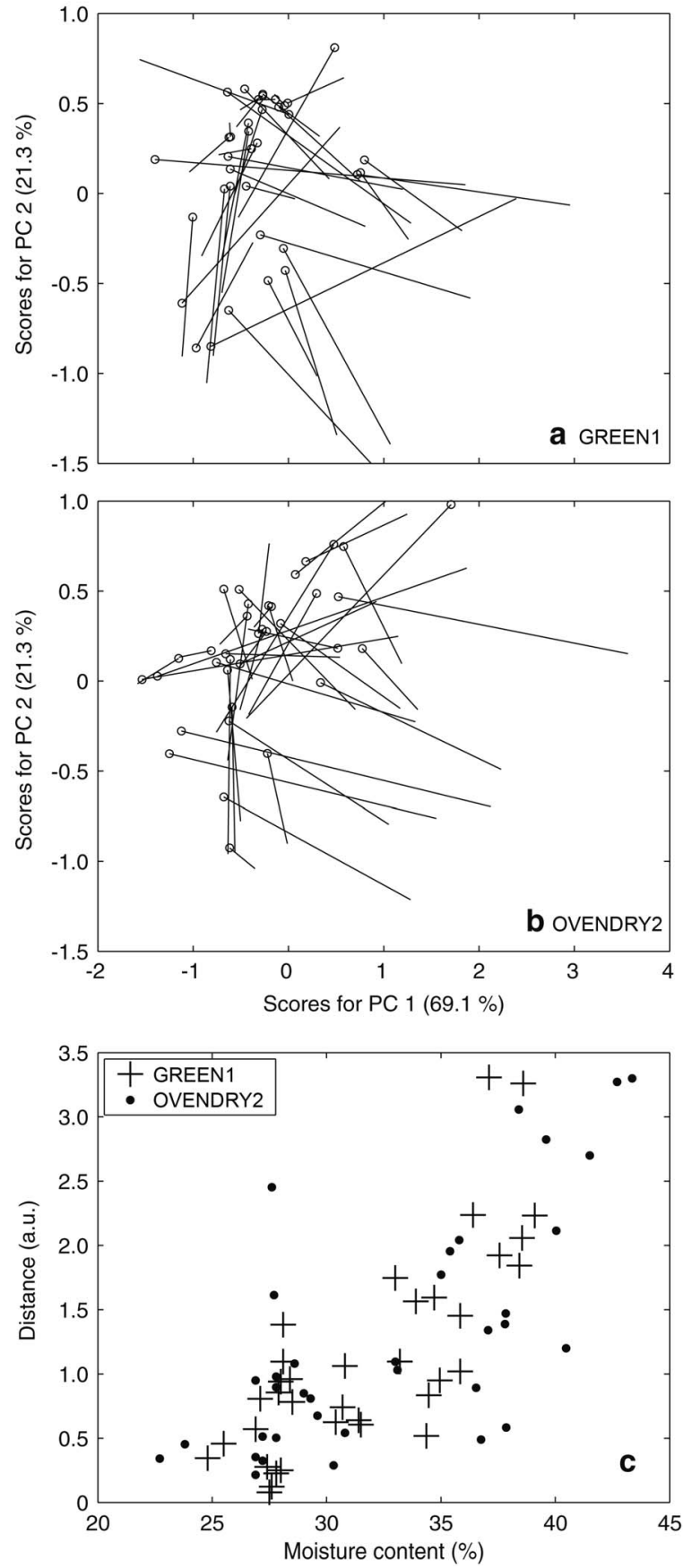

Figure 4 Principal component analysis of the 2 (sample types $) \times 36$ (specimens $) \times 2$ (temperatures $)=144$ FID relaxation curves summarized in Figure 3. Scores for factor 1 vs. scores for factor 2 are shown separately for the two sample types, green specimens in a) and dried and remoistened specimens in b). Each line connects the position of a sample at $+20^{\circ} \mathrm{C}$ with its position at $-20^{\circ} \mathrm{C}$ (marked by a circle). c) The distances between the positions at +20 and at $-20^{\circ} \mathrm{C}$ (as seen in Figures $4 \mathrm{a}$ and $4 \mathrm{~b}$ ) vs. the moisture content of the specimens at $+20^{\circ} \mathrm{C}$.

\section{Acknowledgements}

The authors wish to thank Ulla Gjøl Jacobsen for her invaluable and never tiring technical support during the cumbersome experi- ments that formed the basis of this work. LGT acknowledges funding from The Danish Research Council for Technology and Production Science (project no. 26-02-0100).

\section{References}

Almeida, G., Hernández, R.E. (2006a) Changes in physical properties of yellow birch below and above the fiber saturation point. Wood Fiber Sci. 38:74-83.

Almeida, G., Hernández, R.E. (2006b) Changes in physical properties of tropical and temperate hardwoods below and above the fiber saturation point. Wood Sci. Technol. 40:599-613.

Araujo, C.D., MacKay, A.L., Hailey, J.R.T., Whittall, K.P., Le, H. (1992) Proton magnetic resonance techniques for characterization of water in wood: application to white spruce. Wood Sci. Technol. 26:101-113.

Barkas, W.W. (1936) Wood-water relationships, 2: the fibre saturation point of beech wood. Proc. Phys. Soc. 48:576-588.

Cox, J., McDonald, P.J., Gardiner, B.A. (2010) A study of water exchange in wood by means of 2D NMR relaxation correlation and exchange. Holzforschung 64:259-266.

Engelund, E.T., Thygesen, L.G., Hoffmeyer, P. (2010) Water sorption in wood and modified wood at high values of relative humidity. Part 2: Appendix. Theoretical assessment of the amount of capillary water in wood microvoids. Holzforschung 64:325-330.

Garvey, C.J., Parker, I.H., Simon, G.P., Whittaker, A.K. (2006) The hydration of paper studied with solid-state magnetisationexchange ${ }^{1} \mathrm{H}$ NMR spectroscopy. Holzforschung 60:409-416.

Green, R.W. (1948) Adsorption of water vapour on collagen and elastin. Trans. Roy. Soc. New. Zeal. 77:24-46.

Griffin, D.M. (1977) Water potential and wood-decay fungi. Ann. Rev. Phytopathol. 15:319-329.

Hermans, P.H. (1949) Physics and Chemistry of Cellulose Fibers. New York-Amsterdam-London-Brussels Elsevier Publishing Co. Inc. pp. 180-196.

Hernández, R.E., Bizoň, M. (1994) Changes in shrinkage and tangential compression strength of sugar maple below and above the fiber saturation point. Wood Fiber Sci. 26:360-369.

Hernández, R.E., Pontin, M. (2006) Shrinkage of three tropical hardwoods below and above the fiber saturation point. Wood Fiber Sci. 38:474-483.

Hill, C.A.S. (2008) The reduction in the fibre saturation point of wood due to chemical modification using anhydride reagents: a reappraisal. Holzforschung 62:423-428.

Hill, C.A.S., Forster, S.C., Farahani, M.R.M., Hale, M.D.C., Ormondroyd, G.A., Williams, G.R. (2005) An investigation of cell wall micropore blocking as a possible mechanism for the decay resistance of anhydride modified wood. Int. Biodet. Biodeg. 55:69-76.

Hoffmeyer, P., Jensen, S.K., Jones, D., Klinke, H.B., Felby, C. (2003) Sorption properties of steam treated wood and plant fibres. In: Proceedings of the First European Conference on Wood Modification, Eds. Van Acker, J., Hill, C., Ghent University, Ghent, April 3-4, pp. 177-189.

Jeffries, R. (1960) Sorption of water by cellulose and eight other textile polymers - part 2: the sorption of water vapour below $100^{\circ} \mathrm{C}$ by textile polymers other than cellulose. J. Textil. Inst. Trans. 51:T399-T418.

Johannessen, E.H., Hansen, E.W., Rosenholm, J.B. (2006) Fluid self-diffusion in Scots pine sapwood tracheid cells. J. Phys. Chem. 110:2427-2434. 
Kekkonen, P.A., Telkki, V.V., Jokisaari, J. (2009) Determining the Highly Anisotropic Cell Structures of Pinus sylvestris in Three Orthogonal Directions by PGSTE NMR of Absorbed Water and Methane. J. Phys. Chem. B 113:1080-1084.

Kelley, S.S., Rials, T.G., Glasser, W.G. (1987) Relaxation behaviour of the amorphous components of wood. J. Mater. Sci. Lett. 22:617-624.

Kollmann, F., Schmidt, E., Kufner, M., Fengel, D., Schneider, A. (1969) Gefüge- und Eigenschaftsänderungen im Holz durch mechanische und termische Beanspruchung. Holz Roh-Werks. 27:407-425.

Menon, R.S., MacKay, A.L., Hailey, J.R.T., Bloom, M., Burgess, A.E., Swanson, J.S. (1987) An NMR determination of the physical water distribution in wood during drying. J. Appl. Polymer Sci. 33:1141-1155.

Petrov, O.V., Furó, I. (2009) NMR cryoporometry: principles, applications and potential. Progr. Nucl. Magn. Reson. Spectros. 54:97-122.

Seborg, C.O., Simmonds, F.A., Baird, P.K. (1938) Sorption of water vapour by papermaking materials: irreversible loss of hygroscopicity due to drying. Paper Trade J. 107:223-228.

Skaar, C. (1988) Wood-Water Relations. Springer-Verlag, Berlin Heidelberg.

Spalt, H.A. (1958) The fundamentals of water sorption by wood. Forest Prod. J. 10:288-295.
Stamm, A.J. (1956) Thermal degradation of wood and cellulose. Ind. Eng. Chem. 48:413-417.

Stamm, A.J. (1964) Wood and Cellulose Science. The Ronald Press Company, New York.

Stone, J.E., Scallan, A.M. (1967) The effect of component removal upon the porous structure of the cell wall of wood. II. Swelling in water and the fiber saturation point. Tappi 50:496-501.

Topgaard, D., Södermann, O. (2001) Diffusion of water absorbed in cellulose fibers studied with 1H-NMR. Langmuir 17:2694-2702.

Thygesen, L.G., Engelund, E.T., Hoffmeyer, P. (2010) Water sorption of wood and modified wood at high values of relative humidity. Part 1: results for untreated, acetylated and furfurylated Norway spruce. Holzforschung 64:315-323.

Tiemann, H.D. (1906) Effect of moisture upon the strength and stiffness of wood. USDA For. Serv. Bull. 70.

Urqhuart, A.R. (1929) The mechanism of the adsorption of water by cotton. J. Text. Inst. 20:T125-T132.

Urquhart, A.R., Eckersall, N. (1930) The moisture relations of cotton, VII - A study of hysteresis. J. Textil. Inst. Trans. 21:T499-T510.

Watt, L.C. (1980) Adsorption-Desorption Hysteresis in Polymers. J. Macromol. Sci-Chem., A14:245-255.

Received December 1, 2010. Accepted May 6, 2011.

Previously published online July 8, 2011. 